Acta vet. scand. $1970,11,103-113$.

From the Department of Virus Research, Karolinska Institutet, and the National Veterinary Institute, Stockholm, Sweden.

\title{
TISSUE CULTURE STUDIES IN BOVINE LEUKOSIS
}

\author{
By \\ G. Hugoson
}

Bovine leukosis is usually subdivided into several types: the juvenile form (Bendixen 1963, Theilen \& Dungworth 1965, Hugoson 1967); the adolescent, thymic form (Dungworth et al. 1964); the skin form (Bendixen; Hugoson 1966) and the adult form (Götze et al. 1954, Wiesner 1967). The last mentioned form predominates in most countries. Essential differences - mainly in the epizootiological pattern - between the forms have been shown to occur (Bendixen; Theilen et al. 1964, Hugoson 1967). Doubts concerning a common aetiology have been expressed.

In the search for the aetiology of the bovine leukosis complex several tissue culture studies have been reported. Most papers deal exclusively with the adult form.

Dutcher et al. (1963) described the morphology of lymph node tissue cultures deriving from cattle with adult leukosis. They observed the development of giant cells, nuclear anomalies and the adsorption of lymphocytes to individual cells. Similar observations were simultaneously reported by Gard \& Rockborn (1963). Hatziolos \& Chang (1963) also mentioned the presence of giant cells in such cultures. Liebermann et al. (1965) observed lymphocytic adsorption and cell anomalies which were, however, to the same extent found in tissue cultures prepared from leukosis cases and "normal" bovines. The isolation from leukotic cattle of a strongly cell-associated viral agent inducing syncytia formation in monolayer cultures has recently been reported by Malmquist et al. (1969). The significance of the agent in the aetiology of bovine leukosis is still unclear. 
Dutcher et al. (1963) also found an unexpectedly high number of tissue cultures from leukotic cattle to be resistant to challenge with vesicular stomatitis virus. Later studies have, however, provided inconclusive results (Dutcher et al. 1967).

The possibility of an autoimmune reaction as the cause of a lymphocytic adsorption phenomenon in leukotic tissue cultures has been suggested by Gard (1966) and Weinhold (1966). Weinhold (1968) also reported a somewhat higher frequency of lymphocytic adsorption in bovine leukocyte cultures when serum from leukotic cattle was used in place of serum from healthy cattle in culture medium. Systematic studies on the influence of different sera on cultivated leukotic and normal bovine lymph node cells have not, however, been reported.

In the paper by Dutcher et al. (1963) 5 juvenile cases - the only reported tissue culture studies on this form - are included. In the cultures from some of the calves a clear perinuclear area was observed in the majority of the cells. Four of them also showed resistance to test infection with vesicular stomatitis virus.

As yet there are no publications dealing with tissue culture studies of the adolescent thymic form or the skin form.

The present investigation is concerned with:

I. A study of the development of primary lymph node tissue cultures deriving from cases of juvenile leukosis and from "normal" bovines.

II. A comparison between bovine cell lines of different origin - several types of leukosis cases and "normal" animals -- with respect to

a) susceptibility to infection with interferon sensitive viruses and

b) growth rate in the presence of different bovine sera.

\section{MATERIAL AND METHODS}

Animals. The designation and other data of the animals concerned in the investigation are shown in Table 1.

Twenty-three bovines were included in the study comprising 6 cases of juvenile leukosis (JL), 1 case of skin leukosis (SL), 9 cases of adult leukosis (AL) and 7 "normal" foetuses or calves $(\mathrm{N})$. 
T a b l e 1. Data concerning the animals and the investigation material included in the study.

\begin{tabular}{|c|c|c|c|c|c|c|}
\hline \multirow{3}{*}{$\begin{array}{l}\text { Diagnosis on } \\
\text { animal being } \\
\text { source of } \\
\text { investigation } \\
\text { material }\end{array}$} & \multirow[t]{3}{*}{$\begin{array}{c}\text { Designation } \\
\text { of animal }\end{array}$} & \multirow[t]{3}{*}{$\begin{array}{l}\text { Age of } \\
\text { animal }\end{array}$} & \multicolumn{3}{|c|}{$\begin{array}{l}\text { Part of the investi- } \\
\text { gation in which the } \\
\text { animal is included }\end{array}$} & \multirow[t]{3}{*}{$\begin{array}{c}\text { Origin } \\
\text { of tissue } \\
\left.\text { culture }^{\star}\right)\end{array}$} \\
\hline & & & \multirow[t]{2}{*}{$\mathbf{I}$} & \multicolumn{2}{|c|}{ II } & \\
\hline & & & & $\mathbf{a}$ & b & \\
\hline Juvenile leukosis & JL 1 & 1 month & & & $x$ & - \\
\hline " & JL 2 & 2 months & & $x$ & $x$ & LN \\
\hline , & JL 3 & $3 \quad$ & & $x$ & $x$ & $\mathbf{L N}$ \\
\hline , & JL 4 & , & & $x$ & $x$ & LN \\
\hline , & JL 5 & 5 & $x$ & $x$ & $x$ & LN \\
\hline 川 & JL 6 & $9 \quad$ & $x$ & $x$ & $x$ & $\mathbf{L N}$ \\
\hline Skin leukosis & SL & 1 month & & $x$ & $x$ & LN \\
\hline Adult leukosis & AL 1 & 5 years & & & $x$ & - \\
\hline " & AL 2 & $5 \quad$ & & & $x$ & - \\
\hline , & AL 3 & $5 \quad$ & & & $x$ & - \\
\hline 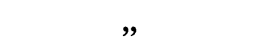 & AL 4 & $5 \quad$, & & $x$ & $x$ & $\mathbf{L N}$ \\
\hline 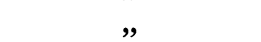 & AL 5 & 6 years & & $x$ & $x$ & $\mathbf{L N}$ \\
\hline 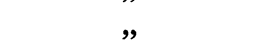 & $\mathrm{AL} 6$ & $6 \quad$ & & $x$ & & $\mathbf{L N}$ \\
\hline , & AL 7 & 7 years & & & $x$ & - \\
\hline 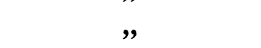 & AL 8 & 7 & & $x$ & $x$ & B \\
\hline , & AL 9 & 11 years & & & $x$ & - \\
\hline Normal & N 1 & Foetus & $x$ & $\times$ & $x$ & LN \\
\hline , & N 2 & , & $x$ & $x$ & $x$ & LN \\
\hline ” & N 3 & , & & $x$ & $x$ & $\mathbf{K}$ \\
\hline " & N 4 & , & & $x$ & & $\mathbf{K}$ \\
\hline ” & N 5 & 6 months & & & $x$ & - \\
\hline , & N 6 & $6 \quad$, & & & $x$ & - \\
\hline " & N 7 & ", & & & $x$ & - \\
\hline
\end{tabular}

*) $\mathbf{L N}=$ Lymph node, $\mathrm{B}=$ Blood, $\mathrm{K}=$ Kidney.

The leukosis cases came from different parts of southern Sweden. The animals were brought to the Veterinary College, Stockholm, for observation.

The "normal" foetuses derived from apparently healthy cows slaughtered at the abattoir of Stockholm, and the "normal" calves belonged to a herd which fulfills the criteria for a "leukosisfree herd" (International Committee 1968).

From slaughtered animals material for the tissue culture preparations was aseptically collected and within $1 \mathrm{hr}$. transported to the laboratory.

Primary tissue cultures. Lymph node tissue cultures were prepared in prescription bottles according to the method described by Gard \& Rockborn (1963). 
In addition to these preparations cells were also seeded in series of Leighton tubes from $2 \mathrm{JL}$ cases and $2 \mathrm{~N}$ cases (Table 1 ). Each day or every 2 days during the first 4 weeks 1 cover slip in each series was removed, fixed in methanol and stained with Giemsa.

Kidneys were minced with scissors, treated with $0.25 \%$ trypsin solution for $20 \mathrm{~min}$. at $37^{\circ} \mathrm{C}$, washed in phosphate buffer solution, suspended in tissue culture medium and transferred to prescription bottles. Two million cells in $15 \mathrm{ml}$ tissue culture medium were seeded in each bottle.

Heparinized blood was added in a 1:10 ratio to tissue culture medium and seeded into Leighton tubes. Each tube received $1 \mathrm{ml}$ of the mixture. The following day the fluid was poured off and the tubes were refed fresh tissue culture medium. When the cover slips were completely covered by a sheet of growing cells, the medium was poured off and the cells were mechanically rubbed off and transferred to prescription bottles. The cells from 10 tubes were pooled in 1 bottle and new tissue culture medium was added.

Cell lines. When tissue cultures whether of lymph node or of kidney or of blood origin completely covered the glass wall of the bottle, subcultures were prepared in new bottles in the same way as was described by Gard $\&$ Rockborn. The cell lines produced in this way served as cell sources for further studies. The cell lines were tested for and found free from mycoplasma infection.

Eagle's basal medium containing $10 \%$ inactivated calf serum and antibiotics was invariably used as growth medium. Eagle's medium and $2 \%$ horse serum were used as maintenance medium in virus inoculated cultures.

Viruses. Pseudorabies virus (PRV), isolated at an outbreak of Aujeszky's disease in Sweden, and vesicular stomatitis virus (VSV) *) were adapted to "normal" bovine embryonic cells (N 1), virus stocks were prepared (stored at $-20^{\circ} \mathrm{C}$ ) and the TCID50 were determined.

On the basis of results from previous titration experiments $10^{-3}-10^{-7}$ dilutions of PRV and VSV were used to infect cell lines repeatedly at intervals varying from 2 weeks to 6 months.

*) The VSV-strain was kindly provided by Dr. K. Cantell, The State Serum Institute, Helsinki. 
Five tissue culture tubes were prepared and used for controls and for each virus dilution. Observations were made every 3 or 4 days during a period of 14 days, and on the basis of total culture degeneration the TCID50 was calculated.

Sera. The influence of 13 leukotic and 3 "normal" sera on different multiplying cell lines was studied. In connection with the preparation of subcultures, cells were counted in a Bürker chamber and seeded in tissue culture tubes. 50,000 cells were used for each tube. Eagle's medium containing $10 \%$ inactivated "normal" or leukotic serum was added to 5 tubes of each tissue culture line. Beginning 3 days after infection each cell line was examined 3 times at 3 - or 4-day intervals and the increase of the cell sheet was estimated and noted.

\section{RESULTS}

I. Proliferation of cells occurred earlier in tubes seeded with leukotic cells. Nuclear budding, nuclear fragmentation, lymphocyte adsorption and giant cell formation were observed - though to a much greater extent in the leukotic cultures - in all 4 cases studied. The morphology of the appearing cell types was similar in cultures originating from leukotic and "normal" animals.

During the development of the primary cultures, 3 different types of proliferating cells could be distinguished:

Type 1: Mononucleated cells characterized by a large spherical nucleus containing several nucleoli and an extensive strongly basophilic cytoplasm. 'These cells were the first cells to be identified and they remained solitary.

Type 2: Polynuclear or giant cells often with 10 to 15 nuclei concentrically bordering a strongly basophilic centre.

Type 3: Mononucleated cells which appeared multicentrically. The nuclei contained several nucleoli and the cytoplasm was wide and moderately basophilic. The cells were rapidly growing, occasionally in clones, and these cells, almost exclusively, constituted the final tissue culture.

Lymphocytes adsorbed to cell types 1 and 2, while nuclear anomalies appeared mainly in cell type 2 . 
T a b l e 2. Results of repeated VSV and PRV test infections of cell lines.

\begin{tabular}{|c|c|c|c|c|c|c|c|c|c|c|c|c|}
\hline \multirow{4}{*}{$\begin{array}{l}\text { Cell line } \\
\text { origin }\end{array}$} & & \multicolumn{11}{|c|}{$\log$. TCID50 } \\
\hline & & \multicolumn{11}{|c|}{ test virus } \\
\hline & & \multicolumn{7}{|c|}{ vsv } & \multicolumn{4}{|c|}{ PRV } \\
\hline & I & II & III & IV & $\mathbf{v}$ & vI & VII & $\overline{\mathbf{x}}$ & $\mathbf{I}$ & II & III & $\overline{\mathbf{x}}$ \\
\hline JL 2 & $\angle 2$. & $\angle 2.5$ & 4.5 & 4.5 & 5.5 & 5.5 & 6.7 & $\leq 4.5$ & 4.8 & 4.4 & 5.6 & 4.9 \\
\hline JL 3 & $\bar{\Sigma} 2$. & $\bar{L} 2.5$ & $\leq 2.6$ & $\leq \mathbf{2 . 5}$ & & & & $\bar{\angle} 2.5$ & 4.6 & 5.4 & 5.6 & 5.2 \\
\hline JL 4 & -7. & & & & & & & 7.2 & & & & \\
\hline JL 5 & 3. & 36 & 4.7 & $\angle 2.5$ & 5.5 & & & $\angle 3.9$ & 4.6 & 4.5 & 5.4 & 4.8 \\
\hline JL 6 & 3. & $\angle 2.5$ & 4.8 & 4.3 & 5.6 & & & $\bar{\angle} 4.0$ & 4.2 & 4.5 & 4.8 & 4.5 \\
\hline SL & $\angle 2$. & $\bar{L} 2.5$ & $\leq \mathbf{2 . 7}$ & $\angle 2.5$ & & & & $\angle 2.6$ & 4.6 & 4.6 & 5.2 & 4.8 \\
\hline AL 4 & $=3$. & 3.5 & $\angle 2.5$ & 4.5 & 4.8 & 5.5 & 4.8 & $\angle 4.2$ & 4.4 & 3.8 & 5.5 & 4.6 \\
\hline AL 5 & $\leq 2$ & $\leq \mathbf{2 . 6}$ & $\bar{\angle} 2.5$ & 4.5 & & & & $\angle 3.0$ & 3.6 & 4.5 & 5.4 & 4.5 \\
\hline AL 6 & 3. & $\angle 2.5$ & $\angle 2.5$ & $\angle 2.5$ & & & & $\angle 2.8$ & 4.3 & 4.5 & 5.6 & 4.8 \\
\hline AL 8 & 3. & $=4.2$ & 5.2 & 4.5 & & & & -4.4 & 4.5 & 5.2 & 5.8 & 5.2 \\
\hline N 1 & 3. & 4.4 & 4.0 & 4.8 & 4.6 & 6.3 & 3.4 & 4.4 & 4.2 & 4.6 & 5.2 & 4.7 \\
\hline N 2 & $\angle 2$. & $\angle 2.6$ & 3.8 & $\angle 2.5$ & 6.2 & & & $\angle 3.5$ & 4.5 & 4.6 & 5.8 & 5.0 \\
\hline N 3 & $=5$. & $=4.2$ & 5.6 & & & & & 5.1 & & & & \\
\hline N 4 & $\leq 2$ & $\leq \mathbf{2 . 5}$ & $\angle 2.5$ & $\angle 2.5$ & & & & $\angle 2.5$ & 4.6 & & & 4.6 \\
\hline
\end{tabular}

$\overline{\mathrm{x}}=$ mean value of all determinations performed.

II a. The results of the interference studies are summarized in Table 2.

The VSV infections gave very irregular results. A slight cytopathic effect was often seen in cultures which later recovered. Some of the cell lines could on one occasion appear to be susceptible and on another resistant. A decreased susceptibility - in comparison with the $\mathrm{N} 1$ culture - was found in several cell lines including 2 controls.

The inoculations of the cell lines with PRV proved to give more uniform results. However, in the cell lines investigated no indications were found suggesting a decreased susceptibility for the test virus.

b. For the part of the study concerned with the influence of different sera on the cell lines the result is presented in Table 3.

The cells of all cell lines showed a high growth rate in the presence of most sera tested. However, retarded growth was occasionally observed in $\mathrm{JL}$ cell lines cultured with $\mathrm{JL}$ or $\mathrm{AL}$ sera, in the AL cell lines with AL sera and in $N$ cell lines with JL, AL and N sera. The cells of the SL cell line showed a good growth in the presence of the 4 sera tested. 
Table 3. The influence of different sera on the growth rate of cell lines.

\begin{tabular}{lcccccccccccccccc}
\hline & \multicolumn{11}{c}{ Sell line } & \multicolumn{11}{c}{ origin } & JL & JL & JL & JL & SL & AL & AL & AL & AL & AL & AL & AL & AL & N & N & N \\
& 1 & 3 & 4 & 6 & & 1 & 2 & 3 & 4 & 5 & 7 & 8 & 9 & 5 & 6 & 7 \\
\hline
\end{tabular}

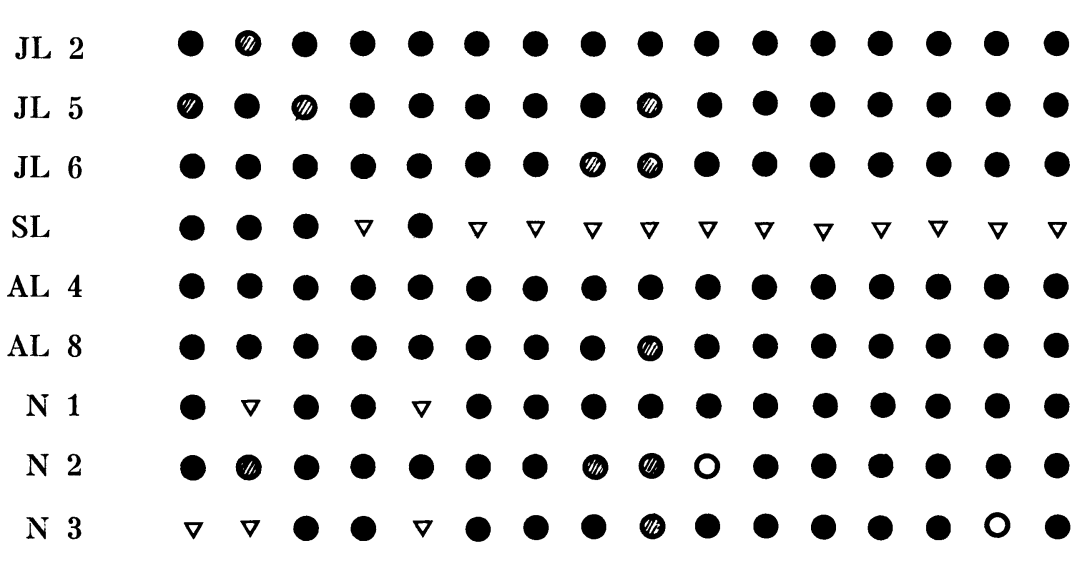

High growth rate. Compact cell sheet at the end of the observation time.

- Less good growth rate. Non-confluent cell sheet at the end of the observation time.

O Very slow growth rate or no growth. Only single cells attached to the glass at the end of the observation time.

$\nabla$ Not examined.

When cell lines were tested against sera deriving from the same animals (JL 6, SL, AL 4, AL 8) only high growth rates were observed.

\section{DISCUSSION}

The clear perinuclear area mentioned by Dutcher et al. (1963) in cultured cells from some juvenile leukosis cases was not observed in the present material.

In the present study the observations of nuclear anomalies, lymphocytic adsorption and giant cell formation made in cultures originating both from juvenile leukosis cases and "normal" foetuses seem to be identical with the findings described in the adult leukosis studies (Dutcher et al. 1963, Gard \& Rockborn 

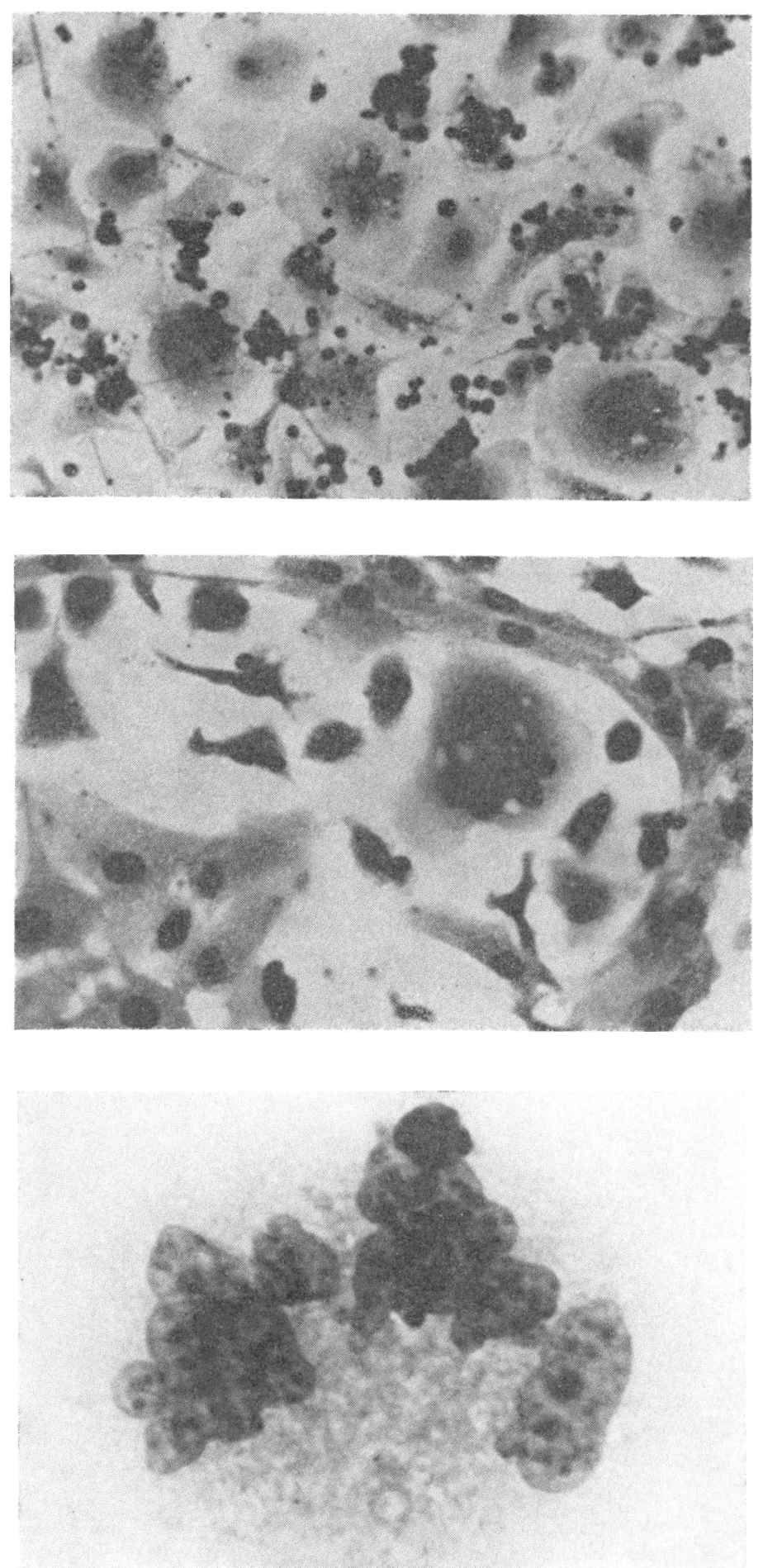

Figu re 1. Four days old primary lymph node tissue culture deriving from juvenile leukosis case (JL 5). Lymphocyte adsorption to individual cells is seen. $(225 \times)$

F i g u r e 2. The same tissue culture preparation after 11 days showing rapidly growing mononucleated cells (cell type 3) surrounding solitary situated mononucleated cells (cell type 1) and a polynuclear cell (cell type 2). $(225 \times)$.

Figure 3. The same preparation (11 days). Polynucleated cell with nuclear budding. $(750 \times)$. 
1963, Hatziolos \& Chang 1963, Liebermann et al. 1965). The similarity between these phenomena and changes produced by some viruses has been stressed (e.g. Gard \& Rockborn). However, the impossibility of finding an unobjectionable normal material makes the evaluation of tissue culture studies in bovine leukosis extremely difficult.

The results of the test infections of the cell lines with VSV were very irregular and consequently inconclusive. A possible explanation for this fact and for the recovery from infection noticed in some cases is that autointerference did occur.

The exposure of the cell lines to PRV infection gave titres to the same level throughout. Thus the results of those test infections cannot be regarded as indicative of an interferon production in any cell line investigated.

The study of the effect of serum on the multiplication of cultivated cells showed in most cases a high growth rate irrespective of the kind of serum used. Growth retardation seen in some cases in the presence of certain sera seemed to be random. This finding and the high rate of multiplication of cells deriving from leukotic animals which were grown in medium containing autologous sera do not support the theory of an autoimmune reaction in bovine leukosis.

\section{REFERENCES}

Bendixen, $H$. J.: Leukosis enzootica bovis. Diagnostik, epidemiologi og bekæmpelse. Thesis, København 1963. (Studies of leukosis enzootica bovis with special regards to diagnosis, epidemiology and eradication). Public Health Service, Wash. 1965, No. 1422.

Dungworth, D. L., G. H. Theilen \& J. Lengyel: Bovine lymphosarcoma in California. II. The thymic form. Path. Vet. 1964, 1, 323-350.

Dutcher, R. M., I. E. Szekely, E. P. Larkin, L. L. Coriell \& R. R. Marshak: Etiological studies on bovine lymphosarcoma. Ann. N.Y. Acad. Sci. 1963, 108, 1149-1162.

Dutcher, R. M., E. P. Larkin, J. J. Tumilowicz, K. Nazerian, C. P. Eusebio, N. D. Stock, G. B. Guest \& R. R. Marshak: Evidence in support of a virus etiology for bovine leukemia. Cancer (Philad.) 1967, 20, 851-856.

Gard, S.: The possible role of immunity mechanisms in leukemogenesis. Comparative leukaemia research. Pergamon Press Ltd., Oxford 1966, 97-103.

Gard, S. \& G. Rockborn: Tissue culture studies of bovine leukosis. Symposium on Comparative Leukemia Research, Hannover 1963, IV, 6. 
Götze, R., G. Rosenberger \& G. Ziegenhagen: Die Leukose des Rindes: Ihre hämatologische und klinische Diagnose. (Leukosis in cattle. Haematological and clinical diagnosis). Mh. Vet.-Med. 1954, 9, $517-526$.

Hatziolos, C. \& C. Chang: A preliminary study on tissue cultures of bovine lymphosarcoma. Ann. N.Y. Acad. Sci. 1963, 108, 12141230.

Hugoson, G.: A case of congenital skin leukosis in a calf. Zbl. Vet.Med., Reihe B 1966, 13, 748-757.

Hugoson, G.: Juvenile bovine leukosis. An epizootiological, clinical, patho-anatomical and experimental study. Acta vet. scand. 1967, Suppl. 22.

International Committee on Bovine Leukosis. Criteria for the determination of the normal and leukotic state in cattle. J. nat. Cancer Inst. 1968, 41, 243-263.

Liebermann, H., D. Urbaneck \& W. Wittmann: Untersuchungen zur Ätiologie der Rinderleukose. (Studies on the aetiology of bovine leukosis). Arch. exp. Vet.-Med. 1965, 19, 1383-1404.

Malmquist, W. A., M. J. Van Der Maaten \& A. D. Boothe: Isolation, immunodiffusion, immunofluorescence, and electron microscopy of a syncytial virus of lymphosarcomatous and apparently normal cattle. Cancer Res. 1969, 29, 188-200.

Theilen, G. H. \& D. L. Dungworth: Bovine lymphosarcoma in California. III. The calf form. Amer. J. vet. Res. 1965, 26, 696-709.

Theilen, G. H., D. L. Dungworth, J. Lengyel \& L. S. Rosenblatt: Bovine lymphosarcoma in California. I. Epizootiologic and hematologic aspects. Hith Lab. Sci. 1964, 1, 96-106.

Weinhold, E.: Lymphozytenadsorption in der Kultur weisser Blutkörperchen des Rindes bei Leukose. (Lymphocyte adsorption in cultures of white blood cells from cattle with leukosis). Zbl. Bakt., 1. Abt. Orig. 1966, 201, 178-185.

Weinhold, E.: Untersuchungen über Riesenzellbildung, Zellphagozytose und Lymphozytenadsorption in der Kultur weisser Blutzellen des Rindes. (Giant-cell formation, cell phagocytosis and lymphocyte adsorption in cultures of white blood corpuscles from cattle). Berl. Münch. tierärztl. Wschr. 1968, 81, 43-45.

Wiesner, E.: Die Leukosen des Rindes. (Bovine leukosis). VEB Gustav Fischer Verlag, Jena 1967.

\section{SUMMARY}

By examining cover slips stained at regular intervals the development of primary lymph node tissue cultures from 2 cases of juvenile bovine leukosis and 2 "normal" foetuses was studied. Secondly, comparisons were made between cell lines prepared from 23 bovines "normal" animals and foetuses, cases of adult leukosis, juvenile leukosis and skin leukosis - with respect to susceptibility to infection with 
interferon sensitive viruses (VSV and PRV) and/or growth rate in the presence of sera from "normal" and leukotic animals.

Nuclear budding, nuclear fragmentation, lymphocyte adsorption and giant cell formation were observed - though to a much greater extent in cultures prepared from the leukosis animals - in all 4 cases studied. No indications of different susceptibility for the test virus infections appeared between cell lines prepared from "normal" and leukotic animals. The growth rate of the cell lines seemed similar irrespective of the kind of serum used.

\section{SAMMANFATTNING \\ Vävnadskulturstudier vid nötkreatursleukos.}

Genom att studera täckglas, som färgats med regelbundna intervaller, följdes den successiva utvecklingen av primära lymfkörtelvävnadskulturer från 2 kalvleukosfall och 2 "normala" foster. Jämförande studier gjordes också av 23 celllinjer, anlagda från "normala" kalvar och foster, fall av vuxenleukos, kalvleukos och hudleukos, med avseende på mottaglighet för interferonkänsliga virus (VSV och PRV) och/eller på tillväxthastighet vid närvaro av sera från "normala" djur och leukotiska djur.

"Nuclear budding", kärnfragmentering, adsorption av lymfocyter till vissa celler samt jättecellsbildning iakttogs i samtliga fall, ehuru i avsevärt större omfattning i kulturer anlagda från leukosfallen. Inga tecken på olika mottaglighet för test-infektionerna framkom mellan cellstammar härrörande från "normala" djur och leukosdjur. Tillväxthastigheten föreföll likartad oberoende av vilket slags serum som ingick i mediet.

(Received June 30, 1969). 